\title{
PENGAWASAN DINAS LINGKUNGAN HIDUP TERHADAP PEMBUANGAN SISA LIMBAH INDUSTRI RUMAH BINATU
}

\author{
Sang Kompiang Kurnia Yudha Putra, I Wayan Arthanaya, Luh Putu Suryani \\ Fakultas Hukum Universitas Warmadewa, Denpasar-Bali, Indonesia \\ yudhakolonk@gmail.com, arthanaya.wayan@gmail.com, putusuryani099@gmail.com
}

\begin{abstract}
Abstrak
Indonesia terkenal sebagai negara berkembang yang kaya akan objek wisata dan masyarakatnya yang banyak membuka bisnis demi mendapatkan penghasilan lebih. Salah satu usaha yang saling berkaitan dengan dunia wisata adalah jasa rumah binatu, bergerak di bidang jasa cuci pakaian, yang membuat bisnis ini diminati banyak warga dan jasanya tidak jarang digunakan oleh tempat pariwisata. Industri rumah binatu berkembang pesat seiring dengan meningkatnya aktivitas warga. Terkait dengan hal tersebut, kajian ini menelaah pengawasan Dinas Lingkungan Hidup terhadap industri rumah binatu dalam pembuangan sisa limbah. Metode penelitian yang digunakan untuk mencapai tujuan-tujuan ini adalah metode penelitian hukum empiris yang dilakukan dengan melakukan penelitian mengkaji permasalahan yang timbul dengan berdasarkan pada aturan-aturan hukum kemudian dikaitkan dengan kenyataan yang ada di lapangan. Dinas lingkungan hidup Kota Denpasar sudah melakukan penertiban terhadap pelanggaran yang terjad; apabila terdapat rumah binatu yang melanggar, surat pernyataan akan diberikan namun jika rumah binatu tersebut tidak memperbaiki sistem pengolahan limbahnya maka surat peringatan diberikan. Jika pelanggaran masih terjadi, penindasan tegas secara tipiring dilakukan dengan bekerjasama dengan satuan polisi pamong praja setempat.
\end{abstract}

Kata Kunci: Pencemaran; Limbah Bahan Berbahaya dan Beracun B3, Jasa; Rumah Binatu

\begin{abstract}
Indonesia has been well-known as a developing country being rich in tourist objects and its people who have been opening many businesses to earn more income. One of the businesses that are interrelated with the world of tourism is a laundry house service, engaged in laundry services, which makes this business attractive to a lot of residents and whose services are often used by tourism places. The laundry house industry is growing rapidly along with the increasing activity of residents. In this regard, this study examines two issues: (1) the supervision of the Environmental Agency on the laundry house industry in the disposal of waste residue and (2) the application of sanctions against perpetrators of violations of waste disposal as seen from the Regional Regulation of the City of Denpasar Number 11 of 2015. The method use to achieve these objectives is the method of empirical legal research which is carried out by conducting research examining the arising problems based on legal rules and then related to the realities in the field. The Environmental Agency of Denpasar City has enforced control of the breaking pf rules that have occurred; if there is a laundry house that violates it, a written statement is be issued but if the laundry house does not repair the waste treatment system, a warning letter is be issued. Ultimately, if the violation continues to take place, decisive repression in light criminal act is executed in collaboration with the local civil service police unit.
\end{abstract}

Keywords: Pollution; Hazardous and Toxic Waste Materials; Services; Laundry House

\section{PENDAHULUAN}

Pada dasarnya Indonesia merupakan Negara yang berlandaskan hukum. Oleh karena itu, hukum yang diterapkan di Indonesia dibuat untuk memberikan manfaat kepada seluruh lapisan masyarakat sehingga pada akhirnya dapat meningkatkan taraf kesejahteraan masyarakatnya (Manik, 2016). Berkenaan dengan hal tersebut yang mempengaruhi tingkat kesejahteraan masyarakat di Indonesia salah satunya adalah faktor ekonomi, faktor sosial, dan lain sebagainya. Tingkat kesejahteraan masyarakat juga timbul dari kualitas hukum yang diberikan oleh Negara, dalam hal ini pemerintah 
menjadi perpanjangan tangan Negara dalam memberikan pelayanan serta pemahaman yang baik terhadap seluruh lapisan masyarakat, sehingga tingkat kesejahteraan pada setiap daerah memiliki perbedaan, tergantung pada pendapatan serta mata pencaharian masyarakatnya.

Di Bali, tingkat kesejahteraan masyarakat tergolong cukup tinggi karena mata pencaharian masyarakat Bali terbilang baik. Mata pencaharian penduduk di Bali sangat beragam yaitu meliputi pekerjaan sebagai petani, pengrajin, pedagang, pegawai, serta berbagai jasa yang berkaitan dengan pariwisata. Pariwisata berkembang pesat seiring berkembangnya zaman dimana setiap pengusaha di bidang pariwisata bersaing satu sama lain demi menggaet para wisatawan dengan beragam variasi barang dan jasa yang ditawarkan guna mempermudah wisatawan melakukan perjalanan di tempat wisata. Dewasa ini, pariwisata serta seluruh aspeknya menjadi sorotan banyak pihak karena memang, pariwisata di Bali sudah sangat berkembang dalam 10 tahun terakhir ini.

Masyarakat membuka usaha jasa pencucian atau sering dibilang laundry bertujuan mempermudah kegiatan seseorang dengan tidak membuang waktu hanya untuk mencuci. Bagi para pemilik tempat wisata yang menyediakan pemandian, hotel dan tempat rekreasi lainnya pasti membutuhkan jasa pencucian, hal ini dimanfaatkan para pemilik usaha binatu untuk menjalin kerjasama jangka panjang dengan perusahaan atau tempat wisata. Tidak hanya perusahaan bahkan banyak juga dari masyarakat yang tinggal diperkotaan bahkan di pedesaan yang menggunakan jasa ini terlebih jasa pencucian tidak memeras isi dompet masyarakat karena biaya yang ditawarkan terbilang murah dan proses pencucian selesai dalam waktu beberapa hari saja membuat masyarakat dapat menggunakan waktu yang biasa digunakan untuk mencuci kini dapat melakukan kegiatan lain atau menambah waktu luang bersama keluarga.

Dewasa ini usaha binatu semakin berkembang, khususnya di daerah Bali. Masyarakat banyak menggunakan jasa pencucian ini karena padatnya aktivitas sehari-hari ditambah dapat mengurangi lelah yang diakibatkan pekerjaan yang dilakukan sehari-hari. . Kebutuhan dalam jasa layanan ini sangat dibutuhkan baik oleh tamu asing maupun warga lokal yang memiliki peningkatan aktivitas akibat pekerjaan yang dilakoni. Tapi dengan banyaknya usaha pencucian yang berdiri di daerah Bali membuat dampak tersendiri bagi lingkungan sekitar dan sisa pembuangan dari air cucian dapat membuat limbah yang merugikan lingkungan, tempat dimana pembuangan sisa air cucian dapat menjadi sarang kuman dan zat beracun hasil detergen yang digunakan mengendap ke permukaan. limbah tersebut dapat mempengaruhi kesuburan tanah dan lingkungan sekitar karena zat yang menggenang secara tidak langsung menumpuk dan menjadi racun.

Pemerintah Kota Denpasar menerbitkan Peraturan Daerah tentang perlindungan dan pengelolaan lingkungan hidup. Dalam Pasal 38 ayat 1 Perda Kota Denpasar nomor 11 Tahun 2015 disebutkan bahwa setiap orang dan/atau Badan usaha yang melakukan pencemaran dan/atau perusakan lingkungan hidup wajib melakukan pemulihan fungsi lingkungan hidup. Maka dari itu, Pemerintah wajib memberikan penanganan hukum yang baik dalam menjaga kelestarian lingkungan serta seluruh aspek yang ada didalamnya. Dengan meningkatnya pariwisata di Bali, maka segala aspek pendukung juga harus kita jaga dan awasi pergerakannya. Salah satunya yang sudah marak terdapat di daerah Bali ini yaitu usaha rumah binatu.

Terkait limbah industri dan pengelolaannya telah dikaji oleh para peneliti dan sarjana. Limbah industri dapat menghasilkan toksik terhadap lingkungannya dan memiliki zat racun (Supraptini, 2002). Terkait dengan usaha industri rumh binatu, pendidikan dan pengawasan terhadap pengelola jua diperlukan agar pengelolaan limbahnya dapat ditangani dengan baik (Samosir, 2014). Hal itu karena limbah industri telah menjadi sebuah masalah yang penyelesaiannya tidak seperti membalikkan telapak tangan. Namun pengawasan dari berbeagai pihak belum maksimal sehingga diperlukan keterlibatan pemerintah dan masyarakat, termasuk pengelola, bukan hanya untuk industri rumah binatu tetapi juga industri lain, seperti industri sagu (Mukarromi \& Ishak, 2017). Kendala lain ialah bahwa kewajiban pihak pemiliki dan pengelola industri tidak terlaksana dengan baik di beberapa daerah (Yusmidiarti, 2018). Bukti lain menunjukkan bahwa usaha pinatu belum secara maksimal melaksanakan kewajibannya dalam menjamin kualitas lingkungan dengan terhindar dari limbah yang tidak terkontrol (Wirjono \& Raharjono, 2019). Kenyataan ini mempunyai tingkat intensitas yang tinggi untuk diperhatikan. Untuk menjalan kegiatan pengawasan dan pengendalian terhadap limbah usaha industri diperlukan aturan-aturan hukum yang ketat. Berdasarkan fenomena ini, penelitian kali ini mengalamatkan kajian pada satu isu dari sudut pandang hukum, yakni bentuk dan proses pengawasan Dinas Lingkungan Hidup terhadap industri rumah binatu dalam pembuangan sisa limbah. 


\section{METODE PENELITIAN}

Penelitian ini berfokus pada pencarian informasi secara langsung di lapangan yang berfokus pada efektivitas dan dampak terhadap pengawasan Dinas Lingkungan Hidup tentang pembuangan sisa limbah industri rumah binatu dan analisis dalam informasi yang ditemukan secara konseptual yang berkaitan dengan objek kajian ini. Untuk mewujudkan tujuan ini, penelitian ini didesain dan dilaksanakan dengan menerapkan desan metode penelitian hukum empiris. Desain Penelitian tersebut merupakan suatu jenis penelitian ke lapangan untuk menggali informasi dengan mengaitkan norma hukum yang terdapat dalam peraturan perundang-undangan (Waluyo, 1996).

Selain itu tujuan penelitian ini juga dicapai dengan tidak menyimpang dari hukum positif dan. Penelitian dilaksanakan dengan terjun ke lapangan untuk mengumpulkan informasi dengan berpatokan pada undang-undang sebagai dasarnya. Pendekatan kasus digunakan dalam melihat, mencatat dan memahami permasalahan yang diangkat dengan tidak keluar dari zona hukum positif.

Penelitian ini menerapkan prinsip Penelitian hukum empiris dalam hal dalam pengerjaannya peneliti menelaah isu hukum dengan mendapatkan informasi langsung dari lapangan dan informan didasari peraturan-eraturan hukum yang berlaku di Indonesia (Saebani, 2010). Data yang telah dikumpulkan dianalisis dengan teknik analisis data kualitatif, yang meliputi mengelompokkan data menurut kategori berdasarkan jenis undang-undang yang dijadikan pisau analisis dan menjelaskannya dengak teknik interpretasi. Hasil analisis data disajikan secara tidak formal, atau dengan kata lain dengan metode dekajian menggunakan bentuk-bentuk kata.

\section{HASIL DAN PEMBAHASAN \\ Pengawasan Dinas Lingkungan Hidup terhadap Industri Rumah Binatu terkait Pembuangan Sisa Limbah}

Seiring berkembangnya jaman pengusaha binatu memberikan layanan yang lebih cepat karena kemajuan teknologi dapat dilihat dari proses setrika yang dilakukan banyak pengusaha laundry menggunakan uap untuk melicinkan pakaian sehingga mempercepat proses packing yang selanjutnya dapat dikembalikan kepada pelanggan. Sifat alami masyarakat Indonesia selalu menginginkan hasil bagus namun proses cepat, cara tersebut sangat efisien bagi para pengusaha laundry untuk meminimalisir waktu yang dibutuhkan untuk menyelesaikan cucian satu pelanggan begitu seterusnya dan banyak juga menggunakan jasa cuci expres dimana pakaian dapat kering dan bersih hanya dalam waktu satu hari namun biaya yang dikenakan sedikit lebih mahal dari harga normal. Dengan banyaknya inovasi yang ada saat ini masyarakat dan tempat wisata lebih memilih menggunakan jasa binatu daripada harus membuang waktu untuk mencuci sendiri atau bahkan menyewa pembantu untuk mencuci pakaian mereka.

Bisnis ini kian hari kian menjanjikan di samping banyak masyarakat yang membutuhkan jasa ini para pengusaha binatu juga sudah banyak yang menjalin kerjasama dengan hotel-hotel dan tempat wisata untuk urusan cuci pakaian namun terdapat beberapa dampak dari bisnis ini yang juga sudah ada undang-undang yang mengatur, dengan penjabaran sebagai berikut:

1. Dampak positif

a. Binatu merupakan bisnis yang siapa saja dapat memulainya karena biaya yang sedikit namun sangat dibutuhkan masyarakat.

b. Para pelanggan kebanyakan rutin menggunakan jasa ini karena prosesnya yang cepat dengan harga yang terjangkau dan banyak bonus yang dapat diperoleh.

c. Adanya aturan pemerintah yang mengatur tentang penggunaan jasa laundry dan efek daripada limbah binatu membuat pemilik lebih hati-hati dan sadar pentingnya kebersihan lingkungan bagi orang banyak.

2. Dampak negatif

a. Dalam pemakaian detergen dan sabun cuci digunakan secukupnya agar tidak merusak kesuburan tanah dari hasil pembuangan cucian.

b. Banyaknya usaha laundry tidak mematuhi aturan pemerintah dengan sembarangan membuang limbah sisa cuci pakaian dan jarangnya aduan dari masyarakat membuat pemilik usaha seenaknya menjalankan usaha tanpa memikirkan lingkungan sekitar. 
Pentingnya menjaga lingkungan dapat meningkatkan kualitas hidup manusia dan makhluk lain seperti binatang dan tumbuhan dan membuat rantai makanan menjadi stabil. Semakin banyak orang yang bekerja pada bidangnya masing-masing peduli akan lingkungan maka semakin banyak oksigen yang dapat membuat hidup semakin sehat bahkan dengan lingkungan yang bersih tidak menutup kemungkinan semakin banyaknya wisatawan yang berkunjung serta dapat meningkatkan ekonomi masyarakat indonesia khususnya masyarakat bali yang tinggal dikelilingi oleh objek wisata.

Wawasan yang dimiliki makhluk nomor satu dalam perebutan rantai makanan yaitu manusia seharusnya bisa memilah mana yang dapat merugikan lingkungan mana yang dapat difungsikan menguntungkan lingkungan namun banyak masyarakat yang seperti buta melihat banyaknya limbah yang dihasilkan dari usaha laundry ini dan lebih memilih diam dan tidak mau tau kedepannya akan seperti apa di masa penerus mereka nanti lahir terlebih pemerintah jarang melakukan sidak dan hanya mengeluarkan aturan yang banyak diantara masyarakat tidak tahu hal tersebut.

Mengingat lingkungan adalah kebutuhan mutlak bagi kehidupan makhluk hidup dibumi maka diperlukan perlindungan bagi lingkungan agar tidak merusak atau tercemar. Mengapa lingkungan harus dilindungi adalah pertanyaan mendasar dan tidak mudah untuk dijawab. Pertanyaan mengapa lingkungan harus dilindungi adalah pertanyaan mengenai tujuan peradaban manusia diatas bumi. Lingkungan tidaklah abstrak tetapi menunjukan ruang kehidupan, kualitas hidup dan juga kesehatan kehidupan manusia, termasuk untuk generasi yang akan datang. Terdapat kewajiban umum bagi negara-negara untuk menjamin bahwa aktivitas di wilayah yurisdiksi dan dibawah pengawasan harus menghormati lingkungan negara lain atau wilayah diluar kontrol negara-negara, yang pada saat sekarang ini telah menjadi bagian dari hukum Internasional yang berkaitan dengan lingkungan (Wijoyo \& Efendi, 2017). Hukum sendiri dibuat untuk membatasi tingkah laku manusia yang dapat merugikan orang lain dan lingkungan sekitar dan mengikat bagi siapa saja yang berada di wilayah Indonesia tidak terkecuali wisatawan yang berkunjung.

Pemerataan aturan dilakukan pemerintah demi memajukan negara dan merubah status dari negara berkembang menjadi negara maju. Penegakan hukum harus berlaku adil kepada setiap yang melanggar hukum agar terjalin kepastian hukum yang dapat membuat semua orang mematuhi aturan yang diberlakukan pemerintah tidak memandang ras, suku dan tahta namun seringkali hukum dapat dikalahkan dengan uang banyak terjadi kasus di Indonesia seperti korupsi yang diberi hukuman ringan bahkan ada yang tidak dikenakan sanksi karena para penegak hukum sudah disodori terlebih dahulu dengan uang. Hal itu yang menyebabkan banyak masyarakat yang masih bertanya-tanya tentang arti dari kepastian hukum yang selama ini diberitahukan lewat media-media namun secara langsung masyarakat melihat hal yang berbeda pada kehidupan sehari-hari. Masyarakat secara tidak langsung bahwa hukum dapat ditegakkan hanya pada masyarakat dengan ekonomi menengah kebawah dan tidak berlaku bagi mereka yang memiliki kekuasaan dan ber uang. Pemerintah memiliki peraturan terkait kebersihan lingkungan dan sanksi bagi yang melanggarnya namun baru sedikit yang peduli tentang peraturan tersebut karena beberapa alasan.

Berdasarkan Undang-Undang Nomor 32 Tahun 2009 tentang Perlindungan dan Pengelolaan Lingkungan Hidup disebutkan bahwa jaminan kepastian hukum memberikan perlindungan terhadap hak setiap orang untuk mendapatkan lingkungan hidup yang baik dan sehat sebagai bagian dari perlindungan terhadap keseluruhan ekosistem. Hal ini merupakan pedoman untuk menjaga lingkungan serta sebuah acuan untuk memberikan kepastian hukum terhadap lingkungan (Yusra, 2017).

Dalam berbagai kasus yang menyangkut masalah lingkungan, biasanya industri merupakan subjek paling dominan sebagai dalang yang menyebabkan terjadinya penurunan mutu lingkungan hidup di suatu wilayah atau lingkungan masyarakat tertentu. Pelaku pencemaran lingkungan tidak lain adalah oknum yang bergelut di bidang industri, baik jasa maupun barang. pada penelitian ini, oknum yang dimaksud adalah orang-orang yang memiliki usaha industri rumah binatu yang dengan sadar maupun tidak sadar membuang limbah hasil industri sembarangan atau tidak sesuai dengan aturan pengelolaan limbah sisa industri yang sudah ditetapkan oleh pemerintah setempat.

\section{SIMPULAN DAN SARAN \\ Simpulan}

Pengawasan Dinas Lingkungan Hidup Kota Denpasar sudah berjalan sesuai hukum yang berlaku. Dinas Lingkungan Hidup melaksanakan penertiban terhadap pelanggaran yang terjadi. Dalam perda 
nomor 11 tahun 2015 sudah sangat jelas disebutkan bahwa sanksi yang dikenakan apabila para pengusaha melanggar dari ketentuan-ketentuan yang telah diatur didalamnya terutama terhadap dampak lingkungan, yang diatur dalam pasal 107. Pelanggar pencemaran atau pembuangan sisa limbah industri rumah binatu yang tidak sesuai dengan hukum sudah diberikan sanksi yang sesuai dengan Perda yang berlaku.

\section{Saran}

Kajian ini bertujuan untuk memberi edukasi seluruh lapisan masyarakat khususnya penggiat industri rumah binatu agar dapat memperhatikan pembuangan sisa limbah Industri Rumah Binatu dengan membuat penyaringan sedimen agar kandungan air menjadi netral dan tidak membuat dampak lingkungan menjadi rusak, terutama dalam lingkungan Sungai. Karena sungai merupakan salah satu sumber ekosistem bagi makhluk hidup baik manusia maupun biota lainnya. Penerapan sanksi yang diberikan oleh dinas terkait yang mana pada bidang ini adalah Dinas Lingkungan Hidup Kota Denpasar agar dapat diindahkan oleh pelaku bisnis serta dapat diimplementasikan dengan tegas sesuai dengan Perda Kota Denpasar yang berlaku.

\section{DAFTAR PUSTAKA}

Manik, K. E. S. (2016). Pengelolaan Lingkungan Hidup. Kencana.

Mukarromi, A., \& Ishak, H. (2017). Pengawasan Badan Lingkungan Hidup terhadap Limbah Industri Sagu di Kabupaten Kepulauan Meranti (Studi Kasus Desa Sungai Tohor Kecamatan Tebing Tinggi Timur). Jurnal Online Mahasiswa Fakultas Ilmu Sosial Dan Ilmu Politik Universitas Riau, 4(1), 1-14.

Saebani, B. A. (2010). Metode Penelitian Hukum. CV. Pustaka.

Samosir, B. S. L. (2014). Pelaksanaan Kewajiban Pengelolaan Limbah oleh Pengelola Usaha Laundry dalam Pengendalian Pencemaran Lingkungan di Kota Yogyakarta. UAJY's Library.

Supraptini. (2002). Pengaruh Limbah Industri terhadap Lingkungan di Indonesia. Media Litbang Kesehatan, 12(2), 10-19.

Waluyo, B. (1996). Penelitian Hukum dalam Praktik. Sinar Grafika.

Wijoyo, S., \& Efendi, A. (2017). Hukum Lingkungan Internasional. Sinar Grafika.

Wirjono, E. R., \& Raharjono, A. B. (2019). Implementasi Aktivitas Kualitas Lingkungan pada Usaha Penatu di Kecamatan Depok Sleman Daerah Istimewa Yogyakarta. MODUS, 31(1), 22-47.

Yusmidiarti. (2018). Analisis Pengelolaan Limbah air Usaha Laundry. Jurnal Media Kesehatan, 9(1), 001-113.

Yusra. (2017). Analilis Problema dan Solusi Penegakan Hukum (Pertama). Deepublish. 